\title{
Gitterfehlordnung und physikalische Eigenschaften hexagonaler und kubischer Eiskristalle
}

\section{Doctoral Thesis}

Author(s):

Gränicher, W. H. Heini

Publication date:

1958

Permanent link:

https://doi.org/10.3929/ethz-a-000091992

Rights / license:

In Copyright - Non-Commercial Use Permitted 
Prom. Nr. 2765

Gitterfehlordnung und physikalische Eigenschaften hexagonaler und kubischer Eiskristalle

\author{
Von der \\ EIDGENÖSSISCHEN \\ TECHNISCHEN HOCHSCHULE \\ IN ZÜRICH
}

zur

Erlangung der Würde eines Doktors

der Naturwissenschaften

genehmigte

PROMOTIONSARBEIT

\author{
Vorgelegt von \\ HEINI GRÄNICHER
}

von Bern und Zofingen

Referent: Herr Prof. Dr. P. Scherrer - Korreferent: Herr Prof. Dr. F. Laves

Wiesbaden - Kohlheck

Wiesbadener Graphische Betriebe GmbH 


\title{
Gitterfehlordnung und physikalische Eigenschaften hexagonaler und kubischer Eiskristalle
}

\author{
Von H. GRÄNICHER
}

Mit 10 Abbildungen im Text

(Eingegangen am 8. Januar 1958)

(Der E.T.H. als Promotionsarbeit eingereicht am 19. Juli 1957)

\begin{abstract}
The structural evidence on hexagonal and cubic ice crystals and their physical properties which strongly depend on the hydrogen arrangement are summarized. All possibilities of configurational changes in the ideal and in the real crystal are studied. It is shown that the electric properties can only be explained by the coexistence of ionized states $\left(\mathrm{H}_{3} \mathrm{O}^{+}\right.$and $\left.\mathrm{OH}^{-}\right)$and of orientational defects (doubly-occupied and vacant bonds). These typical lattice imperfections also account for the line breadth of the proton magnetic resonance, the mechanical relaxation and the thermal behaviour (zero-point entropy). For the self-diffusion other independent processes, presumably Scrotrky defects, must be essential. The theoretical considerations have been extended to the case of cubic (diamond) ice and several predictions are made.
\end{abstract}

\section{Auszug}

Die Kenntnisse über die Struktur hexagonaler und kubischerEiskristalle sowie ihre physikalischen Eigenschaften, welche empfindlich von der Anordnung des Wasserstoffatomo abhängen, werden zusammongefaßt. Alle Möglichkeiten für Konfigurationsänderungen im Ideal- und Realkristall werden untersucht. Er läßt sich eindeutig zeigen, daß die elektrischen Eigenschaften nur durch die gleichzeitige Existenz von Ionenzuständen $\left(\mathrm{H}_{3} \mathrm{O}^{+}\right.$und $\left.\mathrm{OH}^{-}\right)$und Orientierungsfehlern (doppeltbesetzte und leere Bindungen) gedeutet werden können. Durch diese charakteristischen Eigengitterfehler können auch die Linienbreite der Protonenspinresonanzen, die mechanische Relaxation und das thermische Verhalten (Nullpunktsentropie) erklärt werden. Für die Selbstdiffusion dagegen sind andere Prozesse - vermutlich SснотткY-Fehlordnung - maßgebend. Die entwickelten Vorstellungen gestatten einige theoretische Voraussagen für das kubische (Diamant-)Eis.

\section{Einleitung}

Wasser und seine feste Phase, das Eis, sind für das gesamte Naturgeschehen von zentraler Bedeutung. In ihren Eigenschaften weichen sie stark von den als normal zu bezeichnenden Flüssigkeiten und 